\title{
Hubungan Status Gizi terhadap Kualitas Hidup pada Pasien Penyakit Ginjal Kronik yang Menjalani Hemodialisis di RSUD Arifin Achmad Provinsi Riau
}

\author{
Ligat Pribadi Sembiring $^{1^{*}}$, Zulfa Nur Hanifah ${ }^{2}$
}

\begin{abstract}
This research was conducted to investigate the relationship between nutritional status and quality of life in CKD patients with hemodialysis at Arifin Achmad Regional Hospital. The design of this research was an analytic study with a cross-sectional approach that obtained primary data from the questionnaire. Based on inclusion and exclusion criteria, showed the total cases were 54 cases, mostly suffered by men(56\%) with an age group 45-64 years by $74.5 \%$. An assessment of medical conditions obtained by $54 \%$ of respondents had a duration of hemodialysis $>12$ months with $74 \%$ had a reduction of weight in a varying range. Assessment nutritional status with SGA-DMS questionnaire showed malnutrition results (84\%) and assessment quality of life with KDQOL-SF36 questionnaire showed the good quality of life results $(57 \%)$. The bivariate analysis used Pearson-Chi-Square with $p=0.003$. Conclusion there was a significant relationship between nutritional status and quality of life in CKD patients with hemodialysis at Arifin Achmad Regional Hospital.
\end{abstract}

Keywords: Chronic Kidney Disease, Hemodialysis, Nutritional Status, Quality of Life

Penyakit ginjal kronik (PGK) merupakan masalah kesehatan yaitu terjadinya peningkatan prevalensi yang signifikan, prognosis penyakit cenderung ke arah buruk serta tingginya biaya untuk terapi. Peningkatan prevalensi PGK di Indonesia memiliki angka yang sangat signifikan. Riset Kesehatan Dasar (Riskesdas) tahun 2018 menunjukkan bahwa prevalensi PGK sebesar 3,8 per 100.000 penduduk di Indonesia. Prevalensi ini meningkat 90\% dibandingkan hasil Riskesdas tahun 2013 yaitu sebesar 2 per 100.000 penduduk di

\footnotetext{
Penulis korespondensi: 1pribs2000@yahoo.com ${ }^{1}$ KJF/KSM Ilmu Penyakit Dalam Fakultas Kedokteran Universitas Riau/ RSUD Arifin Achmad Provinsi Riau. Pekanbaru, Riau, Indonesia

${ }^{2}$ Fakultas Kedokteran Universitas Riau, Pekanbaru, Riau, Indonesia
}

Indonesia. Pola distribusi PGK berdasarkan jenis kelamin terdiri dari 4,17 per 100.000 laki-laki dan 3,52 per 100.000 wanita dengan insidensi puncak pada usia 65-74 tahun. ${ }^{1}$

Manajemen PGK memerlukan banyak aspek untuk dipertimbangkan, salah satunya terapi pengganti ginjal. Terapi pengganti ginjal dapat berupa hemodialisis, Continuous Ambulatory Peritoneal Dialysis (CAPD) maupun transpantasi ginjal. Hemodialisis merupakan metode dialisis yang lebih banyak digunakan sebagai terapi pengganti ginjal dibandingkan metode CAPD dengan perbandingan 62,8 : 1 di Indonesia. Namun secara umum angka mortalitas dari kedua metode cenderung sama. ${ }^{1,2}$

Penyebab terbanyak mortalitas pada PGK yang menjalani hemodialisis adalah penyakit kardiovaskular (40-50\%) kemudian diikuti dengan inflamasi / infeksi (9-18\%) dan malnutrisi (10-60\%). Kondisi malnutrisi pada pasien PGK yang menjalani hemodialisis 
diakibatkan oleh protein energy wasting (keadaan tubuh kehilangan cadangan protein dan masa lemak) dan kekurangan atau kehilangan mikronutrien secara masif. ${ }^{3,4}$ Oleh karena itu, skrining malnutrisi diperlukan dengan cara monitoring status gizi pasien PGK yang menjalani hemodialisis. Monitoring status gizi pasien PGK yang menjalani hemodialisis dapat menggunakan riwayat asupan makan, pengukuran antropometri, parameter biokimia ataupun kuisioner. ${ }^{5}$ Penelitian yang dilakukan oleh Rani, dkk terhadap 90 pasien pasien PGK yang menjalani hemodialisis, dinyatakan pengukuran status gizi menggunakan Subjective Global Assessment-Dialysis Malnutrition Score (SGA-DMS) memiliki kemaknaan yang lebih baik dibandingkan pemeriksaan antropometrik maupun pemeriksaan biokimia. $^{6}$ Selain itu, penelitian yang dilakukan oleh $\mathrm{Su}$ Lis Lim, dkk yang dilakukan terhadap 67 pasien hemodialisis, SGA-DMS memiliki kemaknaan enam kali lebih sensitif daripada SGA konvensional dalam menentukan perubahan status gizi pada pasien hemodialisis. Kuisioner DMS telah dilakukan uji validitas dan realibilitas oleh Steiber, dkk yang melibatkan 153 pasien PGK yang menjalani hemodialisis memiliki hasil valid (nilai koofisien Spearman berkisar antara 0,7-0,8) dan realibel (nilai kappa adalah 0,7$).^{7,8}$

Selain risiko malnutrisi juga perlu dilakukan penilaian kualitas hidup untuk menilai keterbatasan aktivitas fisik dan menilai ketergantungan terhadap orang lain. Kualitas hidup pada pasien hemodialisis cenderung buruk. Hal ini selaras dengan penelitian yang dilakukan di Rumah Sakit Umum Daerah (RSUD) Ambarawa dan di RSUD Ulin Banjarmasin yang menunjukan bahwa sebagian besar pasien PGK yang menjalani hemodialisis memiliki kualitas hidup yang buruk dengan masing masing persentase sebesar $61 \%$ dan $66.66 \%{ }^{9,10}$
Penilaian kualitas hidup pasien PGK yang menjalani hemodialisis yang paling sering digunakan adalah instrumen World Health Organization Quality of Life -BREF (WHOQOL-BREF) dan Kidney Disease Quality of Life - Sort Form 36 (KDQOLSF36). Penelitian Lin T, dkk tentang kualitas hidup mendapatkan bahwa kuisioner WHOQOL-BREF lebih bermakna pada pasien PGK stadium awal dan kuisioner KDQOLSF36 lebih bermakna pada pasien PGK stadium akhir. ${ }^{11}$ Kuisioner KDQOL-SF36versi bahasa Indonesia telah dilakukan uji validitas dan realibilitas oleh Cahyono, dkk yang melibatkan 80 pasien PGK yang menjalani hemodialisis dengan hasil valid (nilai Content Validity Index adalah 1) dan realibel (nilai cronbach's alpha adalah 0,708). ${ }^{12}$

\section{METODE}

Desain penelitian ini adalah penelitian analitik dengan pendekatan cross-sectional yang diperoleh dari data primer berupa kuisioner SGA-DMS dan KDQOL-SF36, yang dilakukan pada seluruh pasien PGK yang menjalani hemodialisis di Unit Hemodialisis RSUD Arifin Achmad pada bulan Agustus 2020 dengan kriteria inklusi: bersedia menjadi responden, usia $\geq 20$ tahun, menjalani hemodialisis $>3$ bulan, menjalani hemodialisis secara reguler dengan minimal frekuensi hemodialisis 2 kali seminggu, dengan kriteria ekslusi: pasien yang tidak mengerti bahasa indonesia, sulit diajak berkomunikasi dan tidak dilakukan penimbangan berat badan. Data yang diperoleh akan dilakukan analisis bivariat menggunakan uji statistik Pearson Chi Square dengan batas kemaknaan $p<0,05$.

\section{HASIL DAN PEMBAHASAN}

\section{Karakteristik Pasien Penyakit Ginjal Kronis yang Menjalani Hemodialisis}

Gambaran karakteristik pasien PGK yang menjalani hemodialisis di RSUD Arifin Achmad provinsi Riau berdasarkan umur dan jenis kelamin dapat dilihat pada tabel 1 . 
Sedangkan gambaran karakteristik pasien PGK yang menjalani hemodialisis di RSUD Arifin Achmad provinsi Riau berdasarkan lama hemodialisa dan penambahan berat badan dapat dilihat pada tabel 2 .

Tabel 1. Distribusi Frekuensi Pasien Penyakit Ginjal Kronis yang Menjalani Hemodialisis di RSUD Arifin Acmad Provinsi Riau berdasarkan Jenis kelamin dan Umur

\begin{tabular}{ccc}
\hline \multirow{2}{*}{ Karakteristik } & \multicolumn{2}{c}{ Jumlah } \\
& Frekuensi (n) & Frekuensi (n) \\
\hline Jenis kelamin & 24 & $44 \%$ \\
Perempuan & 30 & $56 \%$ \\
Laki laki & & \\
& & \\
Kelompok usia & 10 & $79 \%$ \\
$20-44$ tahun & 40 & $7 \%$ \\
$45-64$ tahun & 4 & \\
$\geq 65$ & &
\end{tabular}

Hasil penelitian didapat pasien PGK yang menjalani hemodialisis banyak diderita oleh laki-laki dengan presentase $56 \%$. Hal ini selaras dengan penelitian yang dilakukan oleh Suwanti di RSUD Ambarawa dan penelitian yang dilakukan oleh Cahyono di Rumah Sakit Akademik Universitas Gajah Mada Yogyakarta yang menyatakan pasien PGK yang menjalani hemodialisis lebih banyak diderita oleh laki-laki dengan masing masing presentase $68,3 \%$ dan $53,75 \% .{ }^{9}, 10$

Literatur menyatakan perbedaan jenis kelamin dapat memprediksi progresivitas penyakit hingga tingkat mortalitasnya. Pada pria progresivitas penyakit jauh lebih cepat dan tingkat mortalitasnya lebih tinggi dibandingkan wanita, hal ini dapat terjadi karena beberapa faktor salah satunya adalah ukuran anatomi ginjal. Ukuran anatomi ginjal pada pria lebih besar dibandingkan wanita hal ini berkaitan dengan luas permukaan tubuh yang berbeda pula, namun pria memiliki respon hemodinamik yang mengakibatkan peningkatan fraksi dari filtrasi yang merespon terhadap angiotensin dua sehingga dapat mempercepat proses sklerosis dan fibrosis pada ginjal. Selain itu juga dapat diakibatkan oleh faktor makanan, pria cenderung mengkonsumsi protein dan kalori lebih besar dibanding wanita. Hal ini pula dapat mengakibatkan progresivitas penyakit ke arah buruk dengan rentang waktu yang cepat. Pria juga memiliki testosteron yang bersifat toksik pada ginjal, testosteron dapat menginduksi podosit dan TGF- $\beta 1$ yang berkaitan dengan percepatan proses sklerosis dan fibrosisi ginjal. Testosteron juga menginduksi RAA yang mengakibatkan hipertensi baik secara glomerular maupun secara sistemik, sedangkan esterogen lebih bersifat protektif akibat mekanisme inhibisi terhadap RAA. Hal ini yang menjelaskan angka kejadian penyakit pada pria lebih banyak dibandingkan wanita. ${ }^{13}$

Tabel 2. Distribusi Frekuensi Pasien Penyakit Ginjal Kronis yang Menjalani Hemodialisis di RSUD Arifin Acmad Provinsi Riau berdasarkan Lama Hemodialisa dan Penambahan Berat Badan

\begin{tabular}{ccc}
\hline Karakteristik & \multicolumn{3}{c}{ Jumlah } \\
& $(\mathrm{n})$ & $\begin{array}{c}\text { Prekentase } \\
(\%)\end{array}$ \\
\hline Lama hemodialisis & & \\
$<6$ bulan & 5 & $9 \%$ \\
6-12 bulan & 20 & $37 \%$ \\
$>12$ bulan & 29 & $54 \%$
\end{tabular}

\section{Penambahan berat} badan

\begin{tabular}{lcc}
$\begin{array}{l}\text { Tidak ada } \\
\text { perubahan berat } \\
\text { badan }\end{array}$ & 14 & $26 \%$ \\
$<5 \%$ & 21 & $39 \%$ \\
$5 \%$ hingga $10 \%$ & 15 & $28 \%$ \\
$10 \%$ hingga $15 \%$ & 3 & $6 \%$ \\
$>15 \%$ & 3 & $6 \%$ \\
\hline
\end{tabular}

Usia dapat berkontribusi secara fisiologis maupun dalam menyumbangkan faktor komorbid penyebab PGK. Secara fisiologis proses penuaan akan membuat perubahan stuktur ginjal secara makroskopis dengan penurunan masa ginjal secara menyeluruh akibat perubahan stuktur ginjal secara mikroskopis. Secara mikroskopis perubahan tejadi akibat penurunan jumlah serta ukuran dari nefron akibat sklerosis dari glomerulus, fibrosis dari pericapsular dan terjadi atrofi pada tubulus. Perubahan mikroskopis dan makroskopis ini akan penyebabkan penurunan fungsi ginjal berupa penurunan LFG, hal ini dapat terjadi secara fisiologis dengan atau 
tanpa faktor komorbid. Faktor komobid berperan dalam memperparah kondisi kerusakan ginjal. ${ }^{14}$ Berdasarkan penelitian ini, lama hemodialisis diidentifikasi paling banyak yakni pada kurun waktu $>12$ bulan sebanyak 54\%. Hal ini selaras dengan penelitian yang dilakukan Liza Salawati di RSUD Zainal Abidin Banda Aceh dengan presentase sebesar $66 \% .^{15}$

Lamanya hemodialisis dapat mempengaruhi status gizi melalui proses hemodialisis, melibatkan proses katabolisme yang mengakibatkan kehilangan nutrisi esensial (asam amino, vitamin, protein dan glukosa). Semakin lama pasien menjalani terapi hemodialisis maka juga semakin lama proses katabolisme terjadi, apabila proses ini tidak seimbangkan dengan terapi gizi maka akan berisiko terjadi malnutrisi. ${ }^{16}$ Lama hemodialisis juga mempengaruhi kualitas hidup melalui faktor psikologis. Pasien yang baru menjalani terapi hemodialisis cenderung mengalami stress akibat belum menerima bahwa pasien akan menjalani hemodialisis di sisa umur pasien. Faktor stress dapat menyebabkan kualitas hidup menjadi buruk. Berbeda dengan pasien yang sudah menjalani terapi hemodialisis dalam jangka waktu yang lama sebagian dari pasien sudah menerima dan mengupayakan perbaikan kualitas hidup. ${ }^{17}$

Hasil penelitian juga menyatakan bahwa $74 \%$ pasien akan mengalami penurunan berat badan dalam 3 bulan terakhir dengan range penurunan berat badan yang bervariasi. Hal ini selaras dengan penelitian oleh Chang,dkk yang menyatakan pasien PGK akan mulai mengalami penurunan berat badan pada 5 bulan pertama dengan rata-rata penurunan berat badan $2 \%$ dari indeks masa tubuh awal. ${ }^{18}$

Penurunan berat badan pada PGK dapat diakibatkan oleh cachexia syndrome yaitu suatu kondisi anoreksia berat disertai pengeluaran energi yang relatif banyak sehingga mengakibatkan penurunan cadangan protein. Sindrom ini pada pemeriksaan fisik atau pemeriksaan laboratorium dapat diidentifikasi dengan penurunan albumin dalam darah, penurunan indeks masa tubuh dan kehilangan masa otot. ${ }^{19}$ Penurunan berat badan juga dapat diakibatkan oleh kehilangan masa otot, ini dapat terjadi melalui perantara capcase III yang berperan dalam proteolisis sel dan melalui perantara UbiquitinProteasome system (UPS) yang berberan dalam proses degradasi protein. ${ }^{20}$

\section{Gambaran Status Gizi berdasarkan Kuisioner SGA-DMS}

Gambaran Status Gizi berdasarkan Kuisioner SGA-DMS pasien PGK yang menjalani hemodialisis di RSUD Arifin Achmad provinsi Riau dapat dilihat pada table 3.Penilaian status gizi melalui kuisioner SGADMS didapatkan $15 \%$ responden memiliki status gizi baik, $46 \%$ memiliki status gizi malnutrisi sedang dan 39\% memiliki status gizi malnutrisi berat. Hal ini selaras dengan penelitian Jonardhan, dkk di Rumah Sakit Pendidikan dan Perawatan Tersier Chennai yang juga membagi status gizi berdasarkan tiga kriteria yaitu status gizi baik, malnutrisi sedang dan malnutrisi berat dengan masing masing presentase $3 \%, 90 \%$ dan $6,06 \%{ }^{21}$

Tabel 3. Gambaran Status Gizi berdasarkan Kuisioner SGA-DMS di RSUD Arifin Achmad Provinsi Riau

\begin{tabular}{lcc}
\hline \multicolumn{1}{c}{ Status gizi } & \multicolumn{2}{c}{ Jumlah } \\
& Frekuensi (n) & Frekuensi (n) \\
\hline Normal & 8 & $15 \%$ \\
Malnutrisi sedang & 25 & $46 \%$ \\
Malnutrisi berat & 21 & $39 \%$ \\
\hline
\end{tabular}

Literatur menyatakan $10-60 \%$ pasien PGK yang menjalani hemodialisis akan mengalami malnutrisi. Penyebab utama tingginya angka presentase ini diakibatkan oleh defisiensi mikronutrien dan protein wasting energy. Protein wasting energy menyebabkan malnutrisi melalui enam jalur, yaitu: ${ }^{3}$ 


\section{Melalui disfungsi metabolik}

Disfungsi metabolik ini terjadi akibat akumulasi dari bahan sisa metabolisme oleh tubuh yang menumpuk akibat ginjal yang kehilangan fungsi ekskresi. Penumpukan bahan sisa metabolisme akan mengakibatkan asidosis metabolik, inflamasi yang terjadi secara sistemik serta fluktuasi kadar angiotensin II yang akan menstimulasi sekresi dari capcase III dan UPS yang masing masing bertugas dalam proteolisis sel dan degradasi protein yang akan memicu kehilangan masa otot. Produk sisa dari proses pemecahan otot akan mengakibatkan uremia, sehingga terjadi penurunan nafsu makan secara drastis.

\section{Ketidakseimbangan hormon}

Ketidakseimbangan hormon terjadi pada pasien PGK dengan penyakit dasae diabetes melitus, karena kondisi resistensi insulin juga berperan dalam peningkatan katabolisme protein.

\section{Inflamasi}

Sitokin proinflamasi seperti IL-6, IL8, IL-18, IL-1 $\beta$, TNF $\alpha$ dan C-Reactive Protein(CRP)akan menyebabkan hipoalbuminemia dan elevasi protein sebagai marker terjadinya inflasi. Kondisi ini akan mengakibatkan anorexia berat, penurunan pemasukan protein serta reduksi dari sintesis protein yang diidentifikasi sebagai protein wasting energy.

4.Perubahan stuktur sistem pencernaan.

Kondisi disfungsi metabolik yang mengakibatkan uremia akan mempengaruhi intestinal epithelial barrier dengan mengganggu proses absorbsi pada saluran cerna.

\section{Perubahan fungsional pada lambung}

Protein wasting energy juga diakibatkan oleh efek gastropharesis yaitu lambung membutuhkan waktu lebih lama untuk melakukan pengosongan lambung atau delayed gastric emptying. Proses ini akan mengakibatkan sekresi senyawa tertentu seperti gastrin, chlecystokinin dan gastic inhibitor polipeptida yang mengakibatkan dispepsia, berkurangnya porsi makan, muntah serta refluks gastroesofagus yang akan mengakibatkan penurunan pemasukan nutrisi.

\section{Efek dari proses dialisis}

Dialisis khususnya hemodialisis dapat berkontribusi dalam protein wasting energy melalui fase yang unik. Ketika darah dari dalam tubuh mengenai membran hemodialisis akan mengakibatkan peningkatan pengeluaran sitokin proinflamasi dan mengeluarkan oksidatif stress yang akan memperparah protein wasting energy yang sudah terjadi sebelum proses dialisis terjadi, juga dapat terjadi kehilangan albumin secara masif pada proses hemodialisis.

\section{Gambaran Kualitas Hidup berdasarkan Kuisioner KDQOL-SF36}

Gambaran kualitas hidup berdasarkan Kuisioner KDQOL-SF36 pasien PGK yang menjalani hemodialisis di RSUD Arifin Achmad provinsi Riau dapat dilihat pada tabel 4.

Tabel 4. Gambaran Kualitas Hidup berdasarkan Kuisioner KDQOL-SF36 di RSUD Arifin Acmad Provinsi Riau

\begin{tabular}{lcc}
\hline \multirow{2}{*}{ Kualitas Hidup } & \multicolumn{2}{c}{ Jumlah } \\
& Frekuensi (n) & Frekuensi (n) \\
\hline $\begin{array}{l}\text { Kualitas Hidup } \\
\text { Baik }\end{array}$ & 31 & $57 \%$ \\
$\begin{array}{l}\text { Kualitas Hidup } \\
\text { Buruk }\end{array}$ & 23 & $43 \%$ \\
\hline
\end{tabular}

Penilaian kualitas hidup dengan kuisioner KDQOL-SF36 di Unit Hemodialisis RSUD Arifin Achmad Provinsi Riau didapatkan modus sebesar $57 \%$ responden diidentifikasi dengan kualitas hidup baik. Hal ini selaras dengan penelitian yang dilakukan oleh Putri,dkk di RSUP Dr. M Djamil Padang dengan presentase sebesar $54,8 \% .^{22}$ Namun hasil ini bertolak belakang dengan penelitian yang dilakukan Aryzky,dkk di RSUD Ulin Banjarmasin $(66,66 \%)$ yang menyatakan 
sebagian besar pasien memiliki kualitas hidup yang buruk. ${ }^{10}$

Perbedaan hasil penelitian di beberapa rumah sakit menunjukan bahwa selain status gizi ada faktor lain yang dapat berkontribusi dalam menentukan kualitas hidup, seperti penelitian oleh Danies dkk di RSUD Dr. Hardjono Ponorogo yang menyatakan bawa faktor sosial demografis seperti jenis kelamin dan status pendidikan juga dapat mempengaruhi kualitas hidup. Jenis kelamin khususnya pada pria cenderung memiliki kehidupan sosial dan aktivitas fisik yang lebih baik daripada wanita, hal ini menjadi salah satu faktor yang dapat membantu perbaikan kualitas hidup. Selain itu, status pendidikan juga berkontribusi berkaitan dengan tingkat pemahaman terkait penyakit yang diderita, sehingga pada pasien dengan tingkat pendidikan lebih tinggi cenderung lebih patuh dalam terapi dan menerima pembatasan konsumsi air dan garam daripada dengan tingkat pendidikan lebih rendah. ${ }^{23}$

\section{Hubungan Status Gizi terhadap Kualitas Hidup pada Pasien PGK yang Menjalani Hemodialisis di RSUD Arifin Achmad Provinsi Riau}

Hubungan status gizi terhadap kualitas hidup pada pasien PGK yang menjalani hemodialisis dapat dilihat dalam tabel 5. Analisis bivariat terhadap variabel dependen yaitu status gizi terhadap variabel independen yaitu kualitas hidup menggunakan uji statistik Pearson Chi Squaredengan $\mathrm{p}=0.003$, yang berarti terdapat hubungan yang bermakna antara status gizi terhadap kualitas hidup pada pasien PGK yang menjalani hemodialisis. Hasil penelitian ini didukung oleh penelitian oleh Feroze dkk yang menyatakan terdapat hubungan bermakna antara status gizi terhadap kualitas hidup pasien PGK yang menjalani hemodialisis.
Dalam penelitiannya, Feroze dkk mengidentifikasi status malnutrisi dengan pemeriksaan kadar kreatinin, kadar albumin dan presentase lemak tubuh total, sedangkan pada variabel kualitas hidup diidentifikasi atas kesehatan fisik dan mental. Hasil penelitian tersebut menyatakan bahwa tingkat kualitas hidup akan berbanding lurus dengan kadar kreatinin, kadar albumin namun berbanding terbalik dengan presentase lemak tubuh total. $^{24}$

Tabel 5. Hubungan Status Gizi terhadap Kualitas Hidup pada Pasien PGK yang Menjalani Hemodialisis di RSUD Arifin Achmad Provinsi Riau

\begin{tabular}{llccccc}
\hline & & \multicolumn{4}{c}{ Kualitas Hidup } & \multirow{2}{*}{$p$} \\
\cline { 3 - 6 } & & $\mathrm{n}$ & $\%$ & $\mathrm{n}$ & $\%$ & \\
\cline { 3 - 6 } $\begin{array}{l}\text { Status } \\
\text { Gizi }\end{array}$ & Baik & 8 & 100 & 0 & 0 & 0.003 \\
& & & & & & \\
& $\begin{array}{l}\text { Malnutrisi } \\
\text { Sedang }\end{array}$ & 16 & 64 & 9 & 36 & \\
& $\begin{array}{l}\text { Malnutrisi } \\
\text { Berat }\end{array}$ & 7 & 33. & 14 & 66.7 & \\
& & & 3 & & & \\
\hline
\end{tabular}

Secara spesifik, malnutrisi pada PGK diakibatkan oleh protein wasting energy. Mekanisme protein wasting energy dalam mempengaruhi kualitas hidup melalui penurunan mobilitas fisik, peningkatan perlemahan tubuh dan melalui faktor psikologis. Protein wasting energy juga menyebabkan anorexia, penurunan berat badan akibat hilangnya masa otot dan inflamasi. Inflamasi akan memicu sitokin proinflamasi yang juga berperan dalam patogenesis depresi yang berperan faktor psikologis melalui neurotransmiter dan neurohormon di otak. Kondisi ini akan memicu perlemahan tubuh, kelelahan yang berlebihan serta memperburuk kondisi hilangnya nafsu makan sehingga menyebabkan penurunan aktivitas fisik maupun penurunan mobilitas fisik. Oleh karena itu, perlu dilakukan perbaikan kondisi malnutrisi pada pasien PGK yang menjalani hemodialisis untuk mengupayakan perbaikan kualitas hidup. ${ }^{25}$ 


\section{KESIMPULAN}

Pasien PGK yang menjalani hemodialisis di RSUD Arifin Achmad Provinsi Riau paling banyak dengan status gizi malnurtisi (85\%) dan dengan kualitas hidup baik (57\%). Terdapat hubungan yang bermakna secara statistik antara status gizi terhadap kualitas hidup pada pasien PGK yang menjalani hemodialisis.

\section{DAFTAR PUSTAKA}

1. Kementrian Kesehatan Republik Indonesia. Hasil utama Riset Kesehatan Dasar (RISKESDAS) 2018. Badan Penelitian dan Pengembangan Kesehatan Kementerian RI tahun. 2018 [cited 2020 Jan 30] : available fromhttp://www.kesmas.kemkes.go.id/asset s/upload/dir_519d41d8cd98f00/files/Hasilriskesdas-2018_1274.pdf

2. Wong B, Brett A S. Comparison of patient survival between hemodialysis and peritoneal dialysis among patients eligible for both modalities. Am J Kidney Dis 2018;71: p.344

3. Lorenber F M. Malnutrition in chronic kidney disease. Frontiers in Pediatrics. 2018;6(161):1-9

4. Suwitra K. Penyakit Ginjal Kronik. In: Setiati, S, Alwi I, Sudoyo AW, Simadibrata M, Setyohadi B, Syam, AF. Buku Ajar Ilmu Penyakit Dalam. Ed 6. Jakarta: Interna Publishing FKUI; 2015. p.2161-7.

5. Alsaran K, Molhem A, Elsayed S, Aldrees A. Nutritional assessment of patients on hemodialysis in a large dialysis center. Saudi journal of kidney diseases and transplantation. Saudi Arabia. 2011;22(4):675-81

6. Rani V, Kavimani S, Soundararajan P, Chamundeeswari D, Gopal K. Correlation between anthropometry, biochemical markers and subjective global assessment dialysis malnutrition score as predictors of nutritional status of the maintenance hemodialysis patients. International Journal of Medical Research \& Health Sciences. 2015; 4(4):852-856
7. Lim S L, Lin XH, Danielns L. 7-Points subjective global assesment is more time sensitive than conventionals subjective global assesment in detecting nutritional changes [Thesis]. Australia : University of Technology ; 2014

8. Steiber A, Leon JB, Secker D, et al. Multicenter study of the validity and reliability of subjective global assessment in the hemodialysis population. J Ren Nutr. 2007;17(5):336-42.

9. Suwanti S, Wakhid A, Taufikurrahman. Gambaran kualitas hidup pasien gagal ginjal kronis yang menjalani terapi hemodialisis. Jurnal Keperawatan Jiwa. 2017;5(2):107-14

10. Aryzki S, Wanda MNR, Susanto Y, Saputera MMA, Putra AMP, Karani. Pengukuran kualitas hidup pasien hemodialisis gagal ginjal kronik di RSUD Ulin Banjarmasin menggunakan instrumen EQ5D. Jurnal Ilmiah Ibnu Sina. 2019;4(1):210-24

11. Lin T C. Comparison of the WHOQOL-BREF and KDQOL-36 in CKD Patients [Paper]. Mexico : National Cheng Kung University; 2011; p.1

12. Cahyono M, Perdana M, Setiyarini S. Validitas dan reliabilitas kidney disease quality of life-36 (KDQOL-36) pada pasien yang menjalani hemodialisis di Rumah Sakit Akademik Universitas Gadjah Mada Yogyakarta. [Skripsi]. Yogyakarta : Universitas Gajah Mada: 2018; p.vi

13. Goldberg I, Krause I. The role of gender in chronic kidney disease. Europe's Medical Journal. 2016;1(2):58-64

14. O'Sullivian ED, Hughes J, Farenbach DA. Renal aging: cause and consequences. Journal of the American Society of Nephrology. 2017;28(2):407-20

15. Husna H, Maulina N. Hubungan antara lamanya hemodialisis dengan kualitas hidup pasien penyakit ginjal kronik di Rumah Sakit Umum Cut Meutia Kabupaten Aceh Utara Tahun 2015. Jurnal Kedoktean dan Kesehatan Malikusaleh. 2015;1(2):39-45

16. Omari AM, Omari LS, Dagash HH, Sweileh WM, Natour N, Zyoud SH. Assessment of nutritional status in the maintenance of haemodialysis patients: a cross-sectional study from Palestine. BMC Nephrol. 2019;20(1):92 
17. Anees M, Hameed F, Mumtaz A, Ibrahim M, Khan M. Dialysis-related factors affecting quality of life in patients on hemodialysis. Iranian journal of kidney diseases. 2011;5(01):9-14.

18. Chang TI, Ngo V, Streja E, Chou JA, TortorinciAR, Kim TH, et al. Association of body weight changes with mortality in incident hemodialysis patients. Nephrol Dial Transplat. 2017;32(1):1649-58

19. Mak RH, Ikizler AT, Kovesdy CP, Raj DS, Stenvinkel P, Kalantar-Zadeh K. Wasting in chronic kidney disease. Journal of Cachexia, Sarcopenia and Muscle. 2011;2(1):9-25.

20. Hen CT, Lin SH, Chen JS, Hsu YJ. Muscle Wasting in hemodialysis patients: new therapeutic strategies for resolving an old problem. ScientificWorldJournal. 2013 okt: p. $1-6$

21. Janardhan V, Soundararajan $P$, Rani NV, Kannan G, Thennarasu P, Chackoet RA, et al. Prediction of malnutrition using modified subjective global assessmentdialysis malnutrition score in patients on hemodialysis. Indian $\mathrm{J}$ Pharm Sci. 2011;73(1):38-45.
22. Wahyuni P, Miro S, Kurniawan E. Hubungan lama menjalani hemodialisis dengan kualitas hidup pasien penyakit ginjal kronik dengan diabetes melitus di RSUP Dr. M Djamil Padang. Jurnal Kesehatan Andalas. 2018;7(4):480-5

23. Pratiwi DJ, Tamtomo DG, Suryono A. Determinants of the quality of life for hemodialysis patients. Indonesian Journal of Medicina. 2019;4(2):145-54

24. Feroze U, Noori N, Kovesoy CP, Molnar MZ, Martin DJ, Reina-Patton AR. Quality of life and mortallity in hemodialysis patients: roles of race and nutritional status. Clinical Journal of Ameican Society of Nephrology. 2011;6(5):1100-11

25. Velasquez MT, Andrews SC, Raj DS. Protein energy metabolism in chronic kidney disease. In: Kimmel PL and Rosenberg ME.Chronic Renal Disease (Second Edition).Kidlington: Elsevier Inc; 2020. p.225-248. 